China Perspectives

2009/4 | 2009

Religious Reconfigurations in the People's Republic of China

\title{
Kevin J. O'Brien (ed.), Popular Protest in China
}

Cambridge, Harvard University Press, 2008, 278 pp.

\section{Dorothy J. Solinger}

\section{OpenEdition}

\section{Journals}

\section{Electronic version}

URL: http://journals.openedition.org/chinaperspectives/4957

DOI: 10.4000/chinaperspectives.4957

ISSN: 1996-4617

\section{Publisher}

Centre d'étude français sur la Chine contemporaine

Printed version

Date of publication: 31 December 2009

ISSN: 2070-3449

\section{Electronic reference}

Dorothy J. Solinger, « Kevin J. O'Brien (ed.), Popular Protest in China », China Perspectives [Online], 2009/4 | 2009, Online since 13 January 2010, connection on 24 September 2020. URL : http:// journals.openedition.org/chinaperspectives/4957; DOI : https://doi.org/10.4000/chinaperspectives. 4957

This text was automatically generated on 24 September 2020.

(c) All rights reserved 


\section{Kevin J. O’Brien (ed.), Popular Protest in China}

Cambridge, Harvard University Press, 2008, 278 pp.

Dorothy J. Solinger

1 This fine collection of chronicles of what were largely short-lived episodes of disturbance and appeal, paired with analyses of what kept them so, sheds much light on the situation of protest in China today. The individual pieces, most of them drawing attention to novel aspects of expressing dissent in contemporary China, and new means of doing so, are all gems. Almost every one of them improves on work the authors published earlier on the same topics they write on here. But these new essays possess much more reference to the au courant comparative social movements, "political process" approach-one that accounts for protest by reference to structural and ideational factors, as well as to the resources available to protesters. The extent of the theoretical and comparative material consulted and assimilated in pretty much every chapter is extremely impressive.

2 The volume is the product of a 2006 conference with two broad objectives: first, to "apply familiar concepts [found in the comparative social movements literature] to China" (p. 13), and second, to "modify or question ideas that do not square with the reality of an authoritarian, non-Western state" (p. 13). Thus at its most ambitious, the book aspires to reformulate a tradition of scholarship on contention in which both the activities that Western institutions permit and the understandings of politics as enacted in the West have long been treated as universal and normative.

3 The book opens with a prologue by Sidney Tarrow, one of the founders of this school of study, followed by an introduction by Kevin O'Brien and Rachel Stern in which they show how the concepts that make up the "process" methodology need to be broadened to account for what political complainants can do in China and the limits upon them. For the most part, however, the chapter writers (with several notable exceptionsWright, Xi Chen, Hurst) succeed much more evidently in achieving the first of the two ambitions assigned them than they do at fulfilling the second -- that is, they do a more excellent job of utilising commonly used conceptions (or explaining why they do not 
precisely fit in China) than they do at systematically recasting these conceptions when necessary.

The central terms that govern the study of social movements are the following: "political opportunity structure," which, in O'Brien and Stern's characterisation refers to the "external factors that facilitate or impede claims making" (p. 13) by pointing to the features of a political system and/or of critical political moments that provide "openings" for behavior antagonistic or disobedient to the government; "resource mobilization," or gathering the wherewithal for mounting opposition; "mobilizing structures," which, again to quote from O'Brien and Stern, are "the ties that connect individuals to groups that organize action" (p. 17); "frames," which point to "shared understandings of a problem and a possible solution" (p. 19), once more in the words of the authors; and protest "repertoires" -- styles or slogans available to sets of actors in specific contexts, often borrowed from the past in a given locale. The big question for each paper is how or how much these conceptions should be bent to account for the case of current China.

5 Most of the authors do in fact document the particular constraints that twist the operation of these concepts in China. Still, it seems a grander opportunity may have been missed. What might have been done with the stories at hand would have been to stretch more systematically for a new overarching framework. Such a scaffold could have used this vocabulary in a way that would compel students of the democratic political world to rethink more abstractly the workings of the mechanisms and the drive behind the relationships that govern political challenge and dissent anywhere in the world. Some might claim that earlier theorists, such as Charles Tilly, have already done this; even his work on protest, however, assumes the opportunity for open opposition, a condition missing in post-1949 China.

6 Such an attempt would have at a minimum to present a consciously standardised approach to the impact exerted by the character of the state (or regime type) in differing contexts, along with a comprehensive targeting of the factors that shape any state's linkages with society and with its own component parts and administrative echelons, in order to specify factors germane to popular offensives against a polity's rulership. This book lacks such a common view even of the political situation in China today.

7 Indeed, several of the authors offer quite disparate models of the nature and mechanics of power in China today. For instance, where Yanfei Sun and Dingxin Zhao, writing on environmental campaigns, claim that fiscal decentralisation has caused the top leadership to withdraw from direct intervention into the operations of local governments, Yongshun Cai puts much emphasis on the pressure local officials face when disruptive tactics threaten what he sees as the ever-present, if unpredictable, possiblity of intervention by central leaders. And Sun and Zhao provide a rich picture of competing alliances-one of local activists linked to journalists, students, and State Environmental Protection officials versus a coalition of powerful hydropower interests and provincial elites linked to leaders or other bureaucracies in the capital. But in other chapters there is no mention of such pluralism. Xi Chen's narrative of petitioning paints a political system clearly in transition, one in which institutions initiated for one purpose (to inhibit collective action) are being appropriated to effect the very opposite goal, while Feng Chen's portrayal of protest leaders in bankrupt firms demonstrates instead a regime that has not changed very much at all, as Cultural Revolutionary 
tactics continue in use and ringleaders from that long-past era have once again emerged at the helm.

Thus, while every one of these accounts is expertly conveyed and rich with new insights, there is no guide for putting them together to forge a coherent statement. And since the extant literature on protest in the West assumes a situation more or less untrammeled by any of the constraints on protest pinpointed by these chapters (the absence of the rights of free speech, of a public sphere, or of a realm for debate; a controlled media combined with obstructions to the flow of information; regime refusal to allow open, politically-oriented social groups and organisations; the perils of combining across geographical or political boundaries; the constant menace of repression), the present book's cataloging of this long list of obstacles begs for a bigger schema than one simply inserting that literature's language into a treatment of Chinese cases.

In short, I sense that between the covers of this volume lie the makings of a bigger theory, one that might be a bit more apt to draw in readers who care more about protest writ large than they do about how it manifests itself in China, one that would significantly add to that literature instead of just borrowing it. One further suggestion is that the chapters might have been usefully organised into themes in the Table of Contents (and thence, throughout the study) rather than just in random order.

Despite these caveats, the assemblage covers a range of fascinating cases (in addition to those already noted above): a stellar study comparing student movements in Taiwan and at Tiananmen, with variable levels of regime repressiveness making for disparate degrees of distrust, radicalism, factionalism, and fear, by Teresa Wright; an innovative use of X.L. Ding's concept of "institutional amphibiousness" to account for the conversion of Mao's mass-line petitioning into today's "trouble-making tactics," by Xi Chen, along with a suggestion of the factors that enabled this transformation (markets, "bureaucratic differentiation"); an emphasis on the structure afforded by regional political economies in constructing laid-off workers' protest frames, in a skillfully wrought piece by William Hurst.

11 There are also studies illustrating two views of the Internet's novel role in protest at present in China, one on its integration into -- and reshaping of -- more old-fashioned protest events, by Yang Guobin, and the other a characteristically creative review of the use of cyberspace to "manufacture dissent" among religious sects, by Patricia Thornton; and a well-crafted investigation of 74 cases of "disruptive collective action" by Yongshun Cai, undertaken in an effort to uncover the factors that determine effectiveness (media coverage, casualties, and large numbers of participants). Carsten Vala and Kevin O'Brien's study of Protestant recruiting seems out of place in the volume. The book ends with historical ruminations by Elizabeth Perry rather than with an effort to plumb a deeper meaning or to mold a more complex conclusion from the material at hand. 